\title{
The profile of the Romanian voter In European elections
}

\author{
Claudia Elena Ionaș \\ University of Political Studies and Public Administration, Bucharest, Romania
}

\begin{abstract}
A European voter is a person who has his own political, social, and cultural background, while simultaneously has the same main goal as do the other Europeans: preserving democracy and the values and benefits emerging from it. With more than 400 million people eligible to vote the result of the European elections has a great impact on European policies and national agendas. The turnout average in 2019 European elections was 50,66\%, but for Romania even though it was close to average, $51.20 \%$, it registered a significant step forward. In 2007 the Romanian people voted for the first time for the European Parliament, but only 29,22\% out of the over 18 million Romanian electors cast the vote. Since then, the trend was similar until last year. What happened in the last decade in Romania to almost double the turnout? The political turmoil determined an increase in political participation: higher turnout and protests against governmental actions. Focused on the European elections, the study of the Romanian's voter profile is based on the results of the exit polls conducted in 2014 and 2019 in the European elections held in Romania, with insight on social and political changes who shaped the electoral behaviour of Romanians as citizens of the European Union.
\end{abstract}

Keywords: behaviour; exit poll; social change; turnout; voting 